\title{
Essential Aspects in Ensuring the Efficient Management of Ovarian Tumors in Children in Case of an Acute or Chronic Setting
}

\author{
Catalin Ion Chiriac-Babei', Andra Rusalim', Adham Charkaoui', Razvan Constantin Datu
}

\begin{abstract}
There is no correlation between the clinical presentation of the patient and the type of ovarian tumor which is causing it. Consequently, the imagistic examination of the patient is crucial in the diagnostic process, but it is not infallible. This study is attempting to emphasize the main differences between the imagistic features of the ovarian tumors compared to the ones discovered intraoperatively, as well as the associated conditions which could prevent getting a proper preoperative diagnosis. The information for the study was gathered retrospectively and it included all the patients admitted over a 5 year period for ovarian tumors. The cohort summed up 130 patients, 12\% presenting ovarian teratomas and out of which only 3 presented malignant features. US examination provided the necessary information, if performed under proper conditions. CT and MRI scans were used only in tumoral staging purposes. In case of benign tumors, laparoscopic surgery was the preferred approach since 10\% of the patients associated obesity and it allowed minimal manipulation of the ovaries. There was no statistically significant difference between the ultrasound versus intraoperative findings. Adnexal torsion remains an intraoperative diagnosis, consequently, it must be considered in any acute surgical abdomen, in patients presenting an ovarian mass.
\end{abstract}

Keywords: ovarian tumors, children, ultrasound, laparoscopic surgery.

\section{Rezumat}

Nu există corelație între prezentarea clinică a pacientelor şi tipul tumorii ovariene care o cauzează. În consecință, examinarea imagistică este crucială în procesul diagnostic, dar nu fără limite. Acest studiu încearcă să evidențieze principalele diferențe dintre caracteristicile imagistice şi cele intraoperatorii, precum şi factorii asociați care pot împiedica obținerea unui diagnostic preoperator corespunzător. Informația pentru studiu a fost adunată retrospectiv şi include toate pacientele internate pentru tumori ovariene pe o perioadă de 5 ani. Cohorta a inclus 130 de paciente, 12\% prezentând teratoame ovariene, dintre care doar 3 maligne. Examinarea ecografică a asigurat informația necesară, dacă a fost efectuată în condițiile corespunzătoare. Examinările CT şi RMN (Rezonanță Magnetică Nucleară) au fost folosite doar în scopul stadializării tumorale. În cazul tumorilor benigne, chirurgia laparoscopică a fost preferată deoarece 10\% dintre pacienți asociau obezitate şi permite manipularea minimă a ovarelor. Nu s-a decelat o diferență semnificativă statistic între rezultatele la examinarea ecografică față de aspectul intraoperator. Torsiunea de anexă rămâne un diagnostic intraoperator, în consecință, trebuie luat în considerare în orice abdomen acut chirurgical, în cazul pacientelor care prezintă o tumoră ovariană.

Cuvinte-cheie: tumori ovariene, pacienți pediatrici, ecografie, chirurgie laparoscopică.

1 Department of Pediatric Surgery, "Grigore Alexandrescu" Clinical Emergency Hospital for Children, Bucharest, Romania
Corresponding author:

Catalin Ion Chiriac-Babei, Iancu de Hunedoara Boulevard, no. $30-32,1^{\text {st }}$ District, Bucharest, Romania.

E-mail: cbcatalin@yahoo.com 


\section{INTRODUCTION}

Considering the unspecific signs and symptoms associated to ovarian tumors, a proper diagnostic procedure must be followed in order to establish the most suitable therapeutic approach. Furthermore, there is no correlation between the clinical presentation of the patient and the type of ovarian tumor which is causing it. Consequently, the imagistic examination of the patient is crucial in the diagnostic process, but it is not infallible. This study is attempting to emphasize the main differences between the imagistic features of the ovarian tumors compared to the ones discovered intraoperatively, as well as the associated conditions which could prevent getting a proper preoperative diagnosis. Another aspect is that certain types of surgical treatment are best avoided in case of suspicion of borderline or malignant tumors, so the findings in ultrasound (US), computed tomography (CT) or magnetic resonance imaging (MRI) are fundamental in obtaining a suggestive description which will subsequently guide the management of that patient. One of the most severe complications related to ovarian tumors is the adnexal torsion, which is rarely diagnosed preoperatively, the clinical manifestations representing the decisive factor in most situations. Therefore, this study is analyzing the hospital's experience in order to enhance the medical assistance of these patients.

\section{MATERIALS AND METHODS}

The information for the study was gathered retrospectively and it included all the patients admitted to the Clinical Emergency Hospital for Children "Grigore Alexandrescu“", Bucharest, starting from the $1^{\text {st }}$ of January 2012 until the $31^{\text {st }}$ of October 2017 for ovarian tumors. The relevant details for the study were: age, clinical manifestations at the onset of the condition, associated conditions, ultrasound features, additional findings in cases which required further imagistic examinations by CT or MRI scans, blood work, type of treatment, and duration of hospital stay, follow-up as well as recurrences. The characteristics discovered at imagistic examinations were compared to the ones observed during surgery, which could help find the possible obstacles in creating proper conditions for the preoperative evaluation of the patient. Choosing the best course of action is crucial since certain benign ovarian tumors benefit from conservative treatment, while those who require surgery may obtain the best results from laparoscopic techniques. Furthermore, acute complications of the ovarian tumors, such as adnexal torsion or hemorrhaging, are not rare. As a result, the imagistic evaluation of the patient must be precise so as to decide upon the indication of surgical treatment, including the type of approach. The circumstances which are imposing multiple imagistic explorations, are also important considering the variety of types of ovarian tumors and the difficulties in identifying the malignant ones, which are rare in children; however, they require certain precautions, so the particularities of the patients who underwent further investigations were emphasized in order to create an efficient diagnostic protocol. Descriptive statistics and t test were used to emphasize the significant aspect of the management of ovarian tumors in case of an acute or chronic setting.

\section{RESULTS AND DISCUSSIONS}

During the 5 year period, a total of 130 patients were admitted to the Clinical Emergency Hospital for Children "Grigore Alexandrescu", Bucharest, for ovarian tumors, and ages raging from 3 days up to 17 years, with an average of 13 years. The main clinical manifestations started with an average of 7 days before presenting to the emergency unit, and they included pain in the lower abdomen, abdominal distension, accompanied by nausea, vomiting or an influenced general state of health in case of adnexal torsion, in this situation the patients presenting even earlier, in the first 12 hours, irregular menstrual cycle, and one case of vaginal bleeding in a toddler who was later discovered to have an ovarian teratoma. $10 \%$ of the cases were diagnosed during routine ultrasound examinations, while $5 \%$ were diagnosed during prenatal ultrasound examinations. With regard to associated conditions, polycystic ovary syndrome was detected in $5 \%$ of the cases and $10 \%$ of the patients were obese.

US examination was the most frequently used, in $85 \%$ of the cases, the rest of the patients undergoing surgical treatment based on clinical manifestations and acute inflammatory syndrome alone $\mathrm{e}^{1,2,3}$. Obtaining an optimal visibility of the internal genital organs in pediatric patients presents certain challenges since the ecography is limited by the thickness of the abdominal wall and it requires a full bladder in order to eliminate the barrier caused by the intestinal contents. Due to these facts, in isolated cases, the ultrasound examination described the possibility of a volvulus or an apendicular mass in patients who were later found to present hemorrhagic cysts and intraabdominal bleeding ( $\mathrm{Fi}^{-}$ gure 1). However, it was highly efficient in diagnosing the majority of the serous or hemorrhagic cysts, sizes ranging from $2 \mathrm{~cm}$ up to $20 \mathrm{~cm}$ diameter. Ovarian teratomas were easily discovered and described by ultra- 
Figure 1. Imagistic findings.

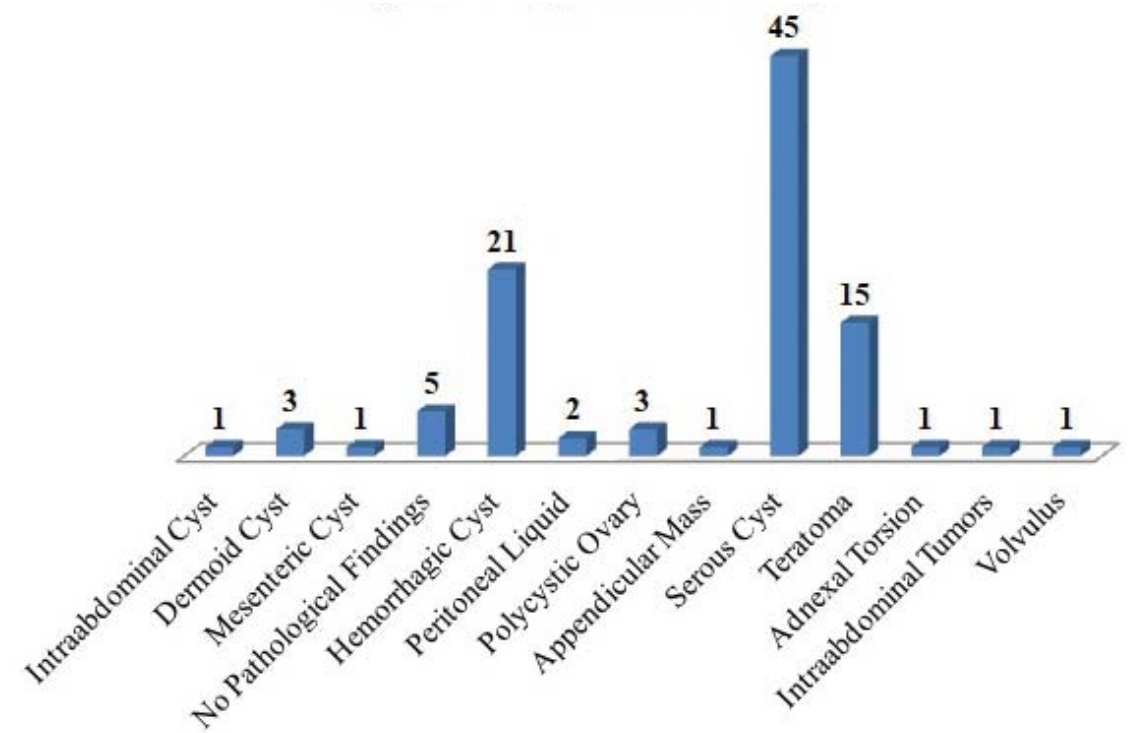

sound examination, but 3 cases needed CT and MRI scans in order to confirm the malignant features of the tumors ${ }^{10}$, since they provide a more detailed picture of the anatomical relations between the tumor and the surrounding structures and they identify any increased lymph nodes. The possibility of an adnexal torsion is raised by the clinical manifestations in conjunction with the results from the US examination, since none of the 5 cases presenting torsion of the fallopian tube were diagnosed preoperatively (Figure 2). One positive aspect is that adnexal torsions were present in just $4 \%$ of the patients with ovarian tumors. One more feature of the ultrasound examination which helps divide benign from borderline or malignant tumors is the color
Doppler evaluation which identified abnormal vascularisation in most of the patients presenting ovarian teratomas, which are occasionally difficult to distinguish from hemorrhagic cysts. Overall, the US diagnosis corresponded to the intraoperative one in over $80 \%$ of the cases. It is important to mention that large serous cysts can occasionally be mistaken for urinary retention, which occurred in 2 adolescent patients, so post micturition US examination is mandatory in certain cases ${ }^{5}$. Regarding the sizes of the tumors in US versus the intraoperative ones, there were no statistically significant differences $(p=0.09)$. CT scan was performed in only $10 \%$ of the patients, in case of difficulties in obtaining the proper conditions for an US examination and on

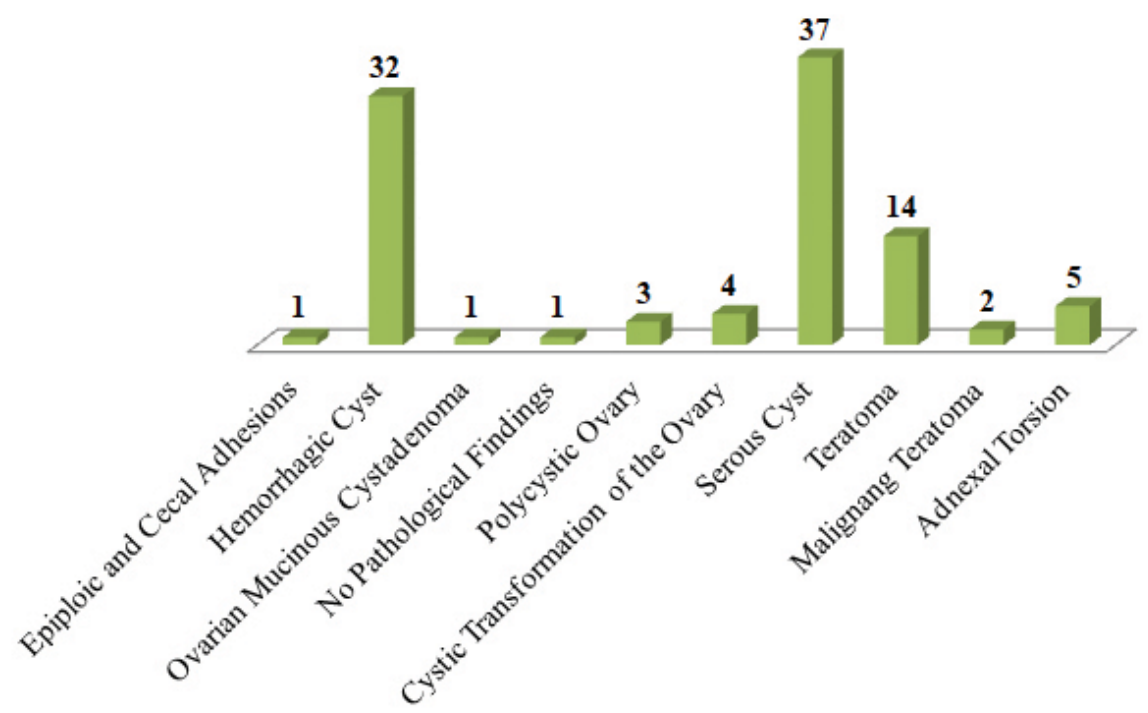

Figure 2. Intraoperative findings. 
suspicion of borderline or malignant tumors in order to extend the area of examination and for tumor staging purposes, while MRI scans were performed in 3 patients with ovarian teratomas for a detailed description of the degree of tumoral invasion ${ }^{11}$.

For a complete diagnosis of the ovarian teratomas as well as for postoperative monitoring for the possibility of recurrence, human chorionic gonadotropin ( $\beta$ HCG), alpha-fetoprotein ( $\alpha-F P)$ and carcinoembryonic antigen 125 (CAE 125) blood levels were determined preoperatively in $75 \%$ of the patients. $25 \%$ of them required urgent surgical treatment, the diagnosis being made intraoperatively, so these blood tests were taken in the first 48 hours after surgery ${ }^{4,12}$.

During the neonatal stage, most of the congenital ovarian cysts required partial oophorectomy or salpingo-oophorectomy. The operability rate was $85 \%$, higher than the one cited in recent studies, due to the size of the cysts, their macroscopic features, such as turbid liquid content and deposits inside the cyst, and lack of compliance regarding regular follow-ups ${ }^{13,14,15,16}$. In toddler stage and early childhood, the ovarian teratoma was the only diagnosed condition the treatment being classical or laparoscopic oophorectomy or salpingo-oophorectomy (Table 1). Serous and hemorrhagic cysts were the most frequent ovarian tumors diagnosed during middle childhood and early adolescence, the type of treatment being dictated by their size and the presence of healthy ovarian tissue. Reconstruction of the ovary was mandatory in every case of open surgery ${ }^{8}$. Laparoscopic surgery is gaining applicability even in case of large serous or hemorrhagic cysts; since it was proven that it is safe in case of benign tumors ${ }^{6,7,8,9,10}$. The average duration of hospital stay was 5 days in classical surgery compared to 3 days in laparoscopic surgery. Peritoneal drainage was required in only $5 \%$ of the patients who underwent open surgery compared to $95 \%$ in laparoscopic surgery. The average duration of the drainage was 24 hours. Only 5\% of the patients who underwent surgical treatment presented recurrences. 25\% of the patients presented small ovarian cysts, less than $4 \mathrm{~cm}$ in diameter, which resolved spontaneously, under

\begin{tabular}{|c|c|c|c|c|c|}
\hline Age group & Diagnosis & $\begin{array}{l}\text { Total number } \\
\text { of cases }\end{array}$ & Size $(\mathbf{c m})$ & Type of treatment & $\begin{array}{c}\text { Number of } \\
\text { cases }\end{array}$ \\
\hline \multirow[t]{5}{*}{ Neonatal stage } & \multirow{4}{*}{ Congenital ovarian cyst } & \multirow{4}{*}{4} & 7 & \multirow{2}{*}{ Partial oophorectomy } & \multirow{2}{*}{2} \\
\hline & & & 3 & & \\
\hline & & & $b$ & Laparuscopic oupriorectomy & 1 \\
\hline & & & 5 & voprivectomy & 1 \\
\hline & Teratoma & 1 & 5 & Salpingo-oophorectomy & 1 \\
\hline Infancy & Congenital ovarian cyst & 1 & 5 & Laparoscopic oophorectomy & 1 \\
\hline \multirow{4}{*}{$\begin{array}{l}\text { Toddler stage + early } \\
\text { childhood }\end{array}$} & \multirow{4}{*}{ Teratoma } & \multirow{4}{*}{4} & 4 & Salpingo-oohporectomy & 1 \\
\hline & & & 9 & Salpingo-oohporectomy & 1 \\
\hline & & & 9 & Oohporectomy & 1 \\
\hline & & & 5 & Laparoscopic-oohporectomy & 1 \\
\hline \multirow[t]{4}{*}{ Middle childhood } & \multirow{2}{*}{ Serous cyst } & \multirow{2}{*}{2} & 7 & Cystectomy and ovarian suture & 1 \\
\hline & & & 5 & Laparoscopic cystectomy & 1 \\
\hline & Hemorrahgic cyst & 4 & $\begin{array}{l}4 \\
5\end{array}$ & Cystectomy and ovarian suture & 4 \\
\hline & Cystic transformation of the ovary & 1 & 6 & Salpingo-oophorectomy & 1 \\
\hline \multirow[t]{12}{*}{ Early adolescence } & \multirow{3}{*}{ Adnexal torsion } & \multirow{3}{*}{5} & \multirow[b]{2}{*}{$5-10$} & $\begin{array}{l}\text { Detorsion of the adnexa, cystectomy } \\
\text { and ovarian suture }\end{array}$ & 2 \\
\hline & & & & $\begin{array}{l}\text { Laparoscopi detorsions of the } \\
\text { adenxa and cystectomy }\end{array}$ & 1 \\
\hline & & & \multirow{3}{*}{$5-20$} & Laparoscopic cystectomy & 7 \\
\hline & \multirow[t]{2}{*}{ Serous cyst } & \multirow[t]{2}{*}{36} & & Cystectomy and ovarian suture & 26 \\
\hline & & & & Partial oophorectomy & 3 \\
\hline & Polucystic ovary & 2 & $5-100$ & Multiple cystectomy & 2 \\
\hline & Cystic transformation of the ovary & 2 & over 10 & oophorectomy & 2 \\
\hline & Ovarian mucinous cystadenoma & 1 & 5 & cystectomy and ovarian suture & 1 \\
\hline & \multirow{2}{*}{ Teratoma } & \multirow{2}{*}{3} & $15-20$ & Oophorectomy & 2 \\
\hline & & & 30 & Salpingo-oophorectomy & 1 \\
\hline & \multirow{2}{*}{ Malignant teratoma } & \multirow{2}{*}{3} & 15 & Salpingo-oohporectomy & 2 \\
\hline & & & 20 & Partial excision & 1 \\
\hline
\end{tabular}


symptomatic medication. The patients were monitored by clinical and US examinations for one month, up to 3 years from discharge. Postoperative check-ups in case of adnexal torsion required laparoscopic evaluation one week after the first menstrual cycle following the surgical treatment.

\section{CONCLUSIONS}

Despite the diversity of ovarian tumors and the limitations of the US examination, it provides the necessary information for establishing the proper course of treatment. It is easily repeatable and it provides a dynamic picture of the evolution of the patient. Further imagistic examinations are required only in case of tumoral staging or difficult US examination. There was no sta-

\section{References}

C. SPINELLI, M. D. (2009). Functional ovarian lesions in children and adolescents: when to remove. Gynecological Endocrinology, 298.

1. Cronen PW1, N. H. (n.d.). Ovarian tumors in children

2. Madhumita Mukhopadhyay, R. M. (2013). Ovarian cysts and tumors in infancy and childhood. Journal of Indian Association of Pediatric Surgeons, 16-19.

3. M Hernon, a. J. (2009). The histology and management of ovarian cysts found in children and adolescents presenting to a children's hospital from 1991 to 2007: a call for more paediatric gynaecologists. An International Journal of Obstetrics and Gynaecology, 181-184.

4. Jennifer H. Aldrink MD, D. O. (October, 26, 2017). Using Quality Improvement Methodology to Improve Ovarian Salvage for Benign Ovarian Masses. Journal of Pediatric Surgery.

5. Andrzej Grabowski, c. a. (2014). Laparoscopy in elective and emergency management of ovarian pathology in children and adolescents. Wideochir Inne Tech Maloinwazyjne, 164-169.

6. Akkoyun 11, G. S. $(2012,12$ 25). https://www.ncbi.nlm.nih.gov/ pubmed/22995767. Retrieved 12 08, 2017, from pubmed.gov: https://www.ncbi.nlm.nih.gov/pubmed/22995767

7. Dani O. Gonzalez MD1, J. N. (n.d.). Variability in Surgical Management of Benign Ovarian Neoplasms in Children. Journal in Pediatric Surgery. tistically significant difference between the ultrasound versus intraoperative findings. Adnexal torsion remains an intraoperative diagnosis, consequently, it must be considered in any acute surgical abdomen, in patients presenting an ovarian mass. Ovarian teratomas are more common during infancy, toddler stage and early childhood, while malignant teratomas were found in early adolescence. Serous and hemorrhagic cysts represent the most frequent ovarian tumors in children, consequently, the surgical treatment is improving towards preserving as much as possible the healthy ovarian tissue, the laparoscopic approach being the preferred one in case of benign ovarian tumors, even in large ones, since cyst puncture, aspiration and excision of the cystic membrane is the best approach.

8. Hong-bae Kim, M. a.-y.-h.-t. (2015). Laparoscopic Ovarian Surgery in Children and Adolescents. Journal of the Society of Laparoendoscopic Surgeons.

9. Tessiatore P1, G. R. (2015). pubmed.gov. Retrieved November 28 2017, from https://www.ncbi.nlm.nih.gov/pubmed/22876534 https://www.ncbi.nlm.nih.gov/pubmed/22876534

10. Amany Mohamed Ali, H. A.-R. (September 16, 2017). Clinicopathological pattern and outcome of pediatric malignant ovarian germ cell tumors: South Egypt Cancer Institute experience. Journal of Pediatric Surgery.

11. Say-Tin Yeap, C.-C. H.-S.-R. (June 2011). Pediatric Malignant Ovarian Tumors: 15 Years of Experience at a Single Institution. Pediatrics \& Neonatology, 140-144.

12. Dr K.-S. Heling. (July 2002). Fetal ovarian cysts: prenatal diagnosis, management and postnatal outcome. Ultrasound in Obstetrics and Gynecology.

13. Onur Erol, 1. M. (2013). Prenatal diagnosis of fetal ovarian cyst: case report and review of the literature. Journal of the Turkish German Gynecological Association, 119-122.

14. K.-S. HELING*, R. C. (2002). Fetal ovarian cysts: prenatal diagnosis, management. Wiley Online Library.

15. Pietro Bagolan, C. G. (2002). The management of fetal ovarian cysts. Journal of Pediatric Surgery, 25-30. 